\title{
ThE MAPPING OF SUBSURFACE TEMPERATURE AND STUDY OF GEOTHERMAL GRADIENT ANOMALY IN THE DISCHARGE AREA IN NORTH SULAWESI
}

\section{Donny R. Wenas*}

Physics Departement

Universitas Negeri Manado, Tondano 95618,

Indonesia

donny_wenas@unima.ac.id

\section{Cyrke A.N. Bujung}

Physics Departement

Universitas Negeri Manado, Tondano 95618,

Indonesia

cyrke@unima.ac.id

*Corrosponding author's Email: donny_wenas@ unima.ac.id 


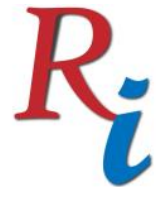

Asia Proceedings of Social Sciences

(APSS)

www.readersinsight.net/APSS

\section{A b s t r a c t}

The aim of this research is to measure and mapping the temperature distribution in several subsurface layers in the manifestation of geothermal warm ground and steaming ground, and analyze the geothermal subsurface gradient, to determine the heat source zone, and the pattern and direction of heat flow from subsurface to surface in Hydrothermal area of Minahasa Indonesia. The method used is direct measurement in the field. To determine the coordinates of geothermal manifestations and location mapping, using remote sensing techniques. The results showed that at a depth of $200 \mathrm{~cm}$ the temperature reaches $102{ }^{\circ} \mathrm{C}$ and the heat source comes from the northeast and from the south. At a depth of $150 \mathrm{~cm}$ the temperature varies from 52 to $100{ }^{\circ} \mathrm{C}$ with an even distribution in almost every direction. At a depth of 50 to $100 \mathrm{~cm}$ the maximum temperature reaches $98{ }^{0} \mathrm{C}$ with heat propagation starting to concentrate then northeast, and then out to the surface in the northeast. The pattern of heat transmission is almost linear along with the geothermal gradient.

\section{Rese a r ch H igh I ight s}

In mapping regional heat flow, an important goal is to separate out near surface processes such as groundwater flow and hydrothermal circulation, from the deeper heat flow from the Earth's interior. Knowledge on the spatial variation in geothermal gradient and heat flow is of direct importance for the growing geothermal investigation and harnessing worldwide. The temperature of rock or soil at and near the surface of the earth results almost entirely from heating by the sun and cooling through radiation, evaporation, and various heat-absorbing processes. At any particular surface location the heat supplied from below the surface is relatively constant; it represents heat from the interior locally supplemented by heat from subsurface oxidation or other local heat sources and is responsible for rock temperatures below the zone where the effect of surface temperatures is perceptible. The temperatures at a given depth in any locality, however, depend not only on the heat flow through the rocks but on the thermal properties of the rock, and on the surface temperature with which the subsurface temperatures are in equilibrium or to which they are adjusting.

\section{Research Objectives}

The aim of this study is to measure and map the temperature distribution in several subsurface layers of warm ground and steaming ground manifestations, and analyze subsurface gradients, to determine the heat source zone, and the pattern and direction of heat flow from the subsurface to surface in the Minahasa Indonesia Hydrothermal area. 


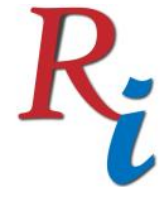

Asia Proceedings of Social Sciences

(APSS)

www.readersinsight.net/APSS

\section{Methodology}

Field data collection is separated based on the type of manifestation and adjusted according to the physical state of the manifestation. For the manifestations of steaming ground, warm ground, and alteration rocks, the measured data are surface temperature and subsurface temperature at depths of $50 \mathrm{~cm}, 100 \mathrm{~cm}, 150 \mathrm{~cm}$, and $200 \mathrm{~cm}$, and also the area of manifestation. Data processing using Excel and the surfer application. After the data obtained from field measurements is obtained, the next step is analysis to obtain subsurface temperature distribution data and temperature gradients.

\section{Results}

Geothermal gradients were obtained which varied between 13.62 to $75.5{ }^{0} \mathrm{C} / \mathrm{m}$. At a depth of $200 \mathrm{~cm}$ the temperature reaches $102{ }^{\circ} \mathrm{C}$ and the heat source comes from the northeast and from the south. At a depth of $150 \mathrm{~cm}$ the temperature varies from 52 to $100{ }^{0} \mathrm{C}$ with an even distribution in almost every direction. At a depth of 50 to $100 \mathrm{~cm}$ the maximum temperature reaches $98{ }^{\circ} \mathrm{C}$ with heat propagation starting to concentrate then northeast, and then out to the surface in the northeast. The pattern of heat transmission is almost linear along with the geothermal gradient.

\section{Findings}

The results showed that the temperature gradient under the manifestation of geothermal energy increased with increasing depth. The pattern of heat flow in the warm ground manifestation is perpendicular from shallow depths to the surface, while the heat flow pattern under the steaming ground manifestation tends to spread towards the North-East.

\section{References}

Hjartarson, Á. (2015). Proceedings World Geothermal Congress 2015. Heat Flow in Iceland. Masum, M. (2014). International Research Journal of Geology and Mining (IRJGM). Geothermal Gradient Calculation Method: A Case Study of Hoffell LowTemperature Field, Se-Iceland, 163-175.

Morgan, P. (2013). Geothermal in the Piceance Basin, Colorado. Geothermal Gradients and Geothermal Opportunities in the Piceance Basin, Colorado, 1-13.

Morgan, P., \& Scott, P. (2014). GRC Transactions, Vol. 38. New Geothermal-Gradient Maps for Colorado's Sedimentary Basins , 155-162.

Rodríguez, C., Geyer, A., Castro, A., \& Villaseñor, A. (2015). Journal of Volcanology and Geothermal Research. Natural equivalents of thermal gradient experiments . 


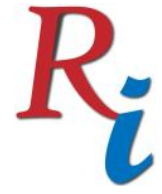

\section{Asia Proceedings of Social Sciences (APSS) \\ www.readersinsight.net/APSS}

Sangin, S., Buntebarth, G., Weller, A., \& Melikadze, G. (2018). International Journal of Terrestrial Heat Flow and Applied Geothermics. Temperature Gradient Measurements in Hydrothermal Areas of Georgia , 14-17.

Author's Biography

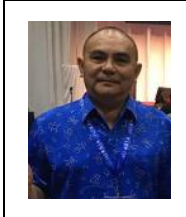

Donny R. Wenas, the third of four children. Born in Manado Indonesia, June 10, 1963. Entered elementary school in 1970 and graduated in 1975. Continue to junior high school in 1976-1979, and finished high school in 1982. Then I studied at IKIP Manado college in the year 1982-1986. A year after graduating, in 1987 I was appointed as a lecturer at Manado State University. Married in 1989 and has 2 children. In 1992-1995 I took my master's degree at UGM Yogyakarta, and in 20062010, I took my doctorate at UNPAD Bandung. At present I am still actively teaching and researching at Manado State University. 